\title{
DMS and MSA measurements in the Antarctic Boundary Layer: impact of $\mathrm{BrO}$ on MSA production
}

\author{
K. A. Read ${ }^{1}$, A. C. Lewis ${ }^{1}$, S. Bauguitte ${ }^{2}$, A. M. Rankin $^{2}$, R. A. Salmon ${ }^{2}$, E. W. Wolff ${ }^{2}$, A. Saiz-Lopez ${ }^{3}$, W. J. Bloss ${ }^{4}$, \\ D. E. Heard ${ }^{5}$, J. D. Lee ${ }^{1}$, and J. M. C. Plane ${ }^{5}$ \\ ${ }^{1}$ Department of Chemistry, University of York, Heslington, York, YO19 4RR, UK \\ ${ }^{2}$ British Antarctic Survey, High Cross, Madingley Road, CB3 0ET, Cambridge, UK \\ ${ }^{3}$ Earth and Space Science Division, Jet Propulsion Laboratory, California Institute of Technology, Pasadena, California \\ 91109, USA \\ ${ }^{4}$ Department of Geography, Earth and Environmental Sciences, University of Birmingham, Birmingham, B15 2TT, UK \\ ${ }^{5}$ Department of Chemistry, University of Leeds, Leeds LS2 9JT, UK
}

Received: 10 December 2007 - Published in Atmos. Chem. Phys. Discuss.: 8 February 2008

Revised: 7 May 2008 - Accepted: 16 May 2008 - Published: 17 June 2008

\begin{abstract}
In situ measurements of dimethyl sulphide (DMS) and methane sulphonic acid (MSA) were made at Halley Station, Antarctica $\left(75^{\circ} 35^{\prime} \mathrm{S}, 26^{\circ} 19^{\prime} \mathrm{W}\right)$ during February 2004-February 2005 as part of the CHABLIS (Chemistry of the Antarctic Boundary Layer and the Interface with Snow) project. DMS was present in the atmosphere at Halley all year (average $38.1 \pm 43 \mathrm{pptV}$ ) with a maximum monthly average value of $113.6 \pm 52 \mathrm{pptV}$ in February 2004 coinciding temporally with a minimum in sea extent. Whilst seasonal variability and interannual variability can be attributed to a number of factors, short term variability appeared strongly dependent on air mass origin and trajectory pressure height. The MSA and derived non-sea salt sulphate (nss- $\mathrm{SO}_{4}^{2-}$ ) measurements showed no correlation with those of DMS (regression $R^{2}=0.039$, and $R^{2}=0.001$ respectively) in-line with the complexity of DMS fluxes, alternative oxidation routes, transport of air masses and variable spatial coverage of both sea-ice and phytoplankton. MSA was generally low throughout the year, with an annual average of $42 \mathrm{ng} \mathrm{m}^{-3}$ $(9.8 \pm 13.2 \mathrm{pptV})$, however MSA: $\mathrm{nss}-\mathrm{SO}_{4}^{2-}$ ratios were high implying a dominance of the addition oxidation route for DMS. Including $\mathrm{BrO}$ measurements into MSA production calculations demonstrated the significance of $\mathrm{BrO}$ on DMS oxidation within this region of the atmosphere in austral summer. Assuming an $80 \%$ yield of DMSO from the reaction of $\mathrm{DMS}+\mathrm{BrO}$, an atmospheric concentration of $\mathrm{BrO}$ equal to $3 \mathrm{pptV}$ increased the calculated MSA production from DMS by a factor of 9 above that obtained when considering only
\end{abstract}

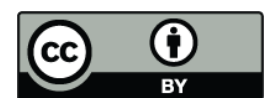

Correspondence to: K. A. Read (km519@york.ac.uk) reaction with the hydroxyl radical. These findings have significant atmospheric implications, but may also impact on the interpretation of ice cores which previously relied on the understanding of MSA and nss-SO $\mathrm{SO}_{4}^{2-}$ chemistry to provide information on environmental conditions such as sea ice extent and the origins of sulphur within the ice.

\section{Introduction}

The presence of sulphur in the global troposphere is from a combination of sources which include sulphate from sea salt, long-range transport of anthropogenic $\mathrm{SO}_{2}$, via DMS from the breakdown of dimethylsulphoniopropionate (DMSP) present in phytoplankton, in addition to intermittent injections from volcanic emissions, land biosphere and biomass burning. As $\mathrm{SO}_{2}$ is rapidly oxidised and either rained out or deposited to particles its impact on the sulphur budget is largely regional rather than global; therefore dimethyl sulphide (DMS), mainly dominated by the smaller biogenic inputs (Liss et al., 1997), is the major source of oxidised sulphur compounds at high southern latitudes away from direct continental source emissions of $\mathrm{SO}_{2}$ (Gondwe et al., 2003). Once in the troposphere the nonsea salt sulphate particles (nss-SO ${ }_{4}^{2-}$ ) and methane sulphonic acid (MSA), resulting from the oxidation of DMS, are the main sources of cloud condensation nuclei $(\mathrm{CCN})$ which is believed to alter the radiation budget of the earth affecting the surface temperature and climate (Charlson et al., 1987).

As well as their importance for $\mathrm{CCN}$ formation, a particular relevance of MSA and nss-SO ${ }_{4}^{2-}$ in Antarctica comes from their use as environmental proxies in ice cores. MSA

Published by Copernicus Publications on behalf of the European Geosciences Union. 
in near-coastal ice cores has been proposed as an indicator of past sea ice conditions (Curran et al., 2003), although it has to be used with care (Abram et al., 2007). The interpretation relies on the ice core concentration (hence the airborne concentration) being determined mainly by production, and to a lesser extent by transport. If the chemical transformation of DMS to MSA was affected by changing conditions, this would further modify the interpretation of this proxy, so this provides another motivation for understanding the processes in this oxidation.

The longest record of specifically DMS measurements in the Southern Hemisphere (S.H.) is from Cape Grim, Tasmania and dates back to 1976 (Ayers et al., 1995a, 1997). Although a great deal of information has been gained from these measurements the complexity of the oxidation processes is such that the fate of DMS is some way from being fully understood. In the Antarctic there have been various measurement campaigns for DMS on ships in the Weddell sea (Davison et al., 1995; Staubes and Georgii, 1993) and comprehensive sulphur studies such as ISCAT 1998/2000 (Investigation of Sulfur chemistry in the Antarctic Troposphere) and SCATE (Sulphur Chemistry in the Antarctic Troposphere Experiment)(MauldinIII et al., 2001; Berresheim et al., 1998a) have taken place at Amundsen-Scott (South Pole, $90^{\circ} 0^{\prime} 0^{\prime \prime} \mathrm{S}$, $\left.139^{\circ} 16^{\prime} 0^{\prime \prime} \mathrm{W}\right)($ Davis et al., 2004), Dumont d'Urville $\left(66^{\circ} 40^{\prime} \mathrm{S}, 140^{\circ} 1^{\prime} \mathrm{E}\right)$ (Legrand et al. 2001), and Palmer Station $\left(64^{\circ} 46^{\prime} \mathrm{S}, 64^{\circ} 03^{\prime} \mathrm{W}\right)$ (Berresheim et al., 1998b), but have focussed mainly on austral summer. Main outcomes of these large campaigns have shown that those coastal stations such as Palmer Station (Antarctic Peninsula) typically see highly variable DMS mixing ratios which are influenced strongly by meteorological conditions and specifically by intensive low pressure storms which provide a means for strong vertical exchange between ocean and atmosphere for this species (Berresheim et al., 1998b). More recently however, a study of five years (1999-2003) of year-round DMS data collected at the Antarctic island site of Dumont d'Urville $\left(66^{\circ} 40^{\prime} \mathrm{S}, 140^{\circ} 1^{\prime} \mathrm{E}\right)$, found that the variability in levels was strongly controlled by the marine biota and therefore by the oceanic DMS concentrations rather than by the meteorological parameters which affect the transfer velocity coefficient $(\mathrm{kw})$, or by changes in atmospheric oxidants (Preunkert et al., 2007). Studies away from the coast, for example at the South Pole, show much lower mixing ratios of DMS and its oxidation products, consistent with the above conclusions (Davis et al., 2004). Although Halley appears to be in a coastal position it is still $15 \mathrm{~km}$ away from the Weddell Sea which for the most part is not considered open ocean; due to the location of Halley DMS mixing ratios could be expected to display features of both types of sites.

Sulphur containing compounds in aerosol, such as sulphate and methane sulphonate (MSA) have been measured year-round since 1983 at Neumayer (Minikin et al., 1998), at
Mawson since 1987 (Savoie et al., 1993), and began at DDU in 1991 as part of the CAASC (Coastal Antarctic Aerosol and Snowfall Chemistry) project (Wolff et al., 1998). These studies find that although MSA concentrations are low during sea ice periods, relatively high values have been seen throughout the year indicating potential origins from either DMS oxidation or as by-products from long-range transport of DMS (Ayers et al., 1997; Minikin et al., 1998). There is still however very little literature on long-term measurements of atmospheric DMS for the Antarctic region.

In recent years the reaction of DMS $+\mathrm{BrO}$ has been explored and found to be $60 \%$ faster than previously reported by Barnes et al. (1991) leading to a rate which is one order of magnitude slower than that for DMS+OH (Ingham et al., 1999). Considering BrO is often present in significantly higher atmospheric mixing ratios than $\mathrm{OH}$ this has an important impact on the rate of production of DMSO and hence also of MSA via the DMS+BrO route. Measurements of $\mathrm{BrO}$ at pptV levels alongside measurements of $\mathrm{OH}$ and DMS made during NAMBLEX on the West Coast of Ireland, led Saiz-Lopez et al. (2004) to calculate the relative oxidation rates of DMS using these laboratory study data and found that, at the levels of $\mathrm{BrO}$ and $\mathrm{OH}$ present there, the oxidation of DMS by $\mathrm{BrO}$ was an order of magnitude faster than that of DMS by $\mathrm{OH}$.

Due to the seasonal inaccessibility of Antarctica long-term trends of $\mathrm{BrO}$ in this region have mainly been studied using integrated measurements obtained from satellites in space (Hegels et al., 1998). These measurements clearly show that $\mathrm{BrO}$ is present in the Antarctic spring all around the Antarctic coastline. In situ measurements of $\mathrm{BrO}$ in the Antarctic are more limited and have been generally of a short-term nature however are also significant in their findings. Kreher et al. (1997) used a zenith sky DOAS instrument to identify sudden large $\mathrm{BrO}$ column enhancement during spring 1995 and during four successive austral springs (1999-2002) at Neumeyer. Friess et al. $(2004,2005)$ used a similar instrument to find that $\mathrm{BrO}$ was present in almost all air masses which had previously been in contact with sea-ice surfaces. In addition, recent shipbourne measurements made over the Antarctic sea ice by Wagner et al. (2007) show the presence of $\mathrm{BrO}$ in late winter, about a month earlier than the satellite measurements. Recent improvements in measurement techniques such as atomic resonance fluorescence and differential absorption spectroscopy (DOAS) have since led to the possibility of more intense long-term studies in this region and during CHABLIS in situ measurements of tropospheric $\mathrm{BrO}$ were made for the first time in the Antarctic boundary layer using a LP-DOAS instrument (Saiz-Lopez et al., 2007). Most previous work on DMS and its oxidation products in Antarctica has focussed on the reactions with the $\mathrm{OH}$ radical (Berresheim et al., 1998b; Jourdain and Legrand, 2001; Legrand et al., 2001) but this work aims to include the impact of varying $\mathrm{BrO}$ mixing ratios on this species' oxidation and particularly on the production of MSA. 


\section{Site}

Halley is situated at $75^{\circ} 35^{\prime} \mathrm{S}, 26^{\circ} 19^{\prime} \mathrm{W}$ on the Brunt Ice shelf in the southeast Weddell Sea, Coastal Antarctica. Measurements were made at the newly commissioned Clean Air Sector Laboratory (CASLab) positioned $1 \mathrm{~km}$ south east of the main station in the Clean Air Sector. Prevailing winds to Halley are from the east and so air often approaches the measurement site from across the ice shelf and eventually the inland plateau. This means that the CASLab is rarely influenced by the station (north of site) and any generators. Aircraft avoided the Clean Air Sector according to protocol and routine access to the CASLab is by foot or by ski. Except for a small amount produced by the base there are no local sources of anthropogenic pollution and therefore measurements are dominated by long-range transport processes and oceanic emissions (Jones et al., 2008).

\section{Experimental}

DMS was measured every hour using a gas chromatograph with flame ionisation detection (Read et al., 2007). The detection limit for this species was $5 \mathrm{pptV}$ and the uncertainty on the measurement $<5 \mathrm{pptV}$. DMS was calibrated on the basis determined in the laboratory that its response is 0.65 times that of propane. Propane was calibrated using a commercial 28 hydrocarbon component in nitrogen calibration cylinder (NPL, UK) at the ppbV level, in addition to a diluted pptV NMHC standard. The relationship between DMS and propane was verified in laboratory experiments both before and after the CHABLIS campaign. Main precision errors in the measurement of DMS and propane arise from peak integration (Read et al., 2007).

Size-segregated aerosol samples were collected on a 7-stage Sierra Instruments high-volume cascade impactor mounted on the roof of the CASlab. Filters were usually changed at fortnightly intervals, and were stored frozen until they could be transported to the UK for analysis. Major anions (chloride, MSA, sulphate and nitrate) and cations (sodium, calcium, magnesium and potassium) were analysed using Dionex ion chromatographs in a clean room at the British Antarctic Survey laboratories in Cambridge. Rankin and Wolff (2003) describe the cascade impactor setup and the analysis techniques in more detail.

The Differential Optical Absorption Spectroscopy (DOAS) instrument was located in the Clean Air Sector Laboratory (CASLab). An effective light path of $8 \mathrm{~km}$ at a height of $5 \mathrm{~m}$ above the snowpack was set up between the CASLab and a retro-reflector array positioned $4 \mathrm{~km}$ to the east. Further information on the instrumental design and spectral de-convolution procedures can be found in Plane and Saiz-Lopez (2006).

$\mathrm{OH}$ and $\mathrm{HO}_{2}$ were measured from a $5 \mathrm{~m}$ high inlet on the roof of a containerised laboratory adjacent north

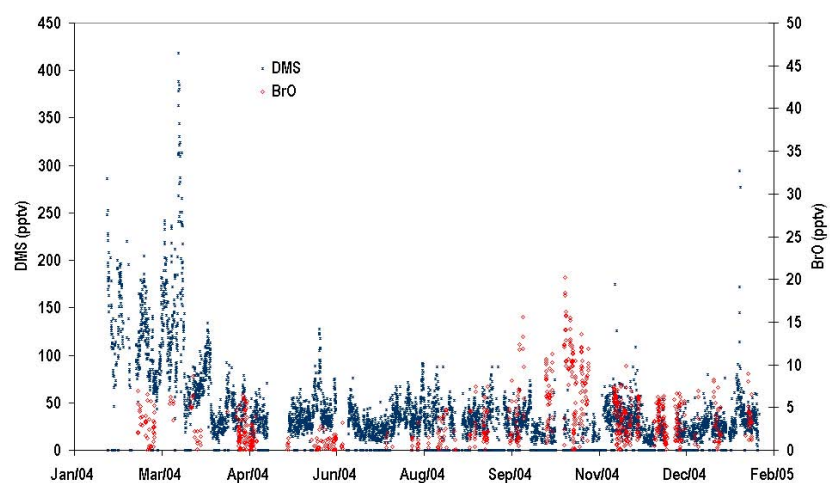

Fig. 1. Time-series of dimethyl sulphide (DMS), and bromine oxide (BrO) for February 2004-February 2005.

of the CASLab. The technique of on-resonance laserinduced fluorescence was used to detect $\mathrm{OH}$, with $\mathrm{HO}_{2}$ measured following chemical conversion through addition of NO. Calibrations were carried out using photolysis of water vapour at $185 \mathrm{~nm}$ and yielded detection limits of $4.8 \times 10^{-3}$ molecules $\mathrm{cm}^{-3}$ and $0.068 \mathrm{pptV}$ for $\mathrm{HO}$ and $\mathrm{HO}_{2}$ respectively. Overall uncertainty for the measurements was calculated to be $\pm 27 \%$. Bloss et al. (2007) describe the experimental set-up in more detail.

\section{Results and discussion}

\subsection{Dimethyl sulphide (DMS)}

DMS measurements from February 2004-February 2005 are illustrated in Fig. 1 along with measurements of $\mathrm{BrO}$ from the Long Path DOAS.

Higher mixing ratios of DMS were expected and observed in the summer associated with both a decrease in sea ice cover and with highest biogenic emissions (Ayers et al., 1995b; Read et al., 2007). The summer (December-February) average seen in this study of $46 \pm 50 \mathrm{pptV}(<5-286 \mathrm{pptV})$ was lower than measurements made by Berresheim et al. (1998b) at Palmer Station who reported an average of $94 \mathrm{pptV}(6-595 \mathrm{pptV})$ during 1994, and also lower than the January-February average of $170 \mathrm{pptV} \pm 180 \mathrm{pptV}$ measured during five summers at DDU between 1999-2003. At DDU the summer concentrations ranged between $60 \mathrm{pptV}$ in 2003, which is more in-line with this study; and $244 \mathrm{pptV}$ in 2002, although the latter excluded two days of extremely elevated mixing ratios of $5000 \mathrm{pptV}$ which would increase the average by a factor of two (Preunkert et al., 2007). Between the studies a major difference was seen in the occurrence of the annual maximum of the measurements which at Halley $(418.1 \mathrm{pptV})$ was in early March rather than in late January like at DDU. Halley is situated further "inland" than most other Antarctic sites; for example, $4^{\circ}(500 \mathrm{~km})$ further south than the site at Neu- 
Table 1. Mean Atmospheric concentrations of $\mathrm{Na}^{+}, \mathrm{Cl}^{-}, \mathrm{SO}_{4}^{2-}$, and MSA over the 2001 (Rankin and Wolff, 2003) and 2004-2005 sampling

\begin{tabular}{lcc}
\hline Ion & $\begin{array}{c}\text { Mean Concentration } \\
\mathrm{ng} \mathrm{m}^{-3} \text { Jan-Dec 2001 }\end{array}$ & $\begin{array}{c}\text { Mean Concentration } \\
\mathrm{ng} \mathrm{m}^{-3} \text { Feb 2004-Feb 2005 }\end{array}$ \\
\hline $\mathrm{Na}^{+}$ & 145 & 94 \\
$\mathrm{Cl}^{-}$ & 272 & 225 \\
$\mathrm{SO}_{4}^{2-}$ & 156 & 99 \\
$\mathrm{MSA}$ & 84 & 42 \\
\hline
\end{tabular}

mayer (Minikin et al., 1998); and so the effect of the ice retreat occurs later and the later peak levels in DMS at Halley appear to reflect this. A temporally comparable study involving a cruise in the Drake passage and around Antarctica in March-April 1986 reported an average value of $106 \mathrm{pptV}$ $\left(4.4 \mathrm{nmol} \mathrm{m}^{-3}\right)$ for DMS (Berresheim, 1987) in-line with the average of $73.7 \pm 63.7 \mathrm{pptV}$ observed during those months in this study. The results from Berresheim et al., also showed high scatter similar to this study with data varying between $16.8 \mathrm{pptV}\left(0.7 \mathrm{nmol} \mathrm{m}^{-3}\right)$ and $235.2 \mathrm{pptV}\left(9.8 \mathrm{nmol} \mathrm{m}^{-3}\right)$, which they attribute to changes in wind speed and wind direction.

Although sea ice cover is vast around the continent for most of the year, even in winter, polynyas (areas of open water) are kept open by the prevailing easterly wind to Halley providing a local region for sea-air transfer of such species and a source of water vapour throughout the year (Wolff et al., 1998). The DMS levels measured at Halley throughout winter (June-August, 28.7 $\pm 20.1 \mathrm{pptV}$ ) and the rest of the year are thought to be due to a combination of small emissions from these polynas and from long-range transport from more northern temperate latitudes (DMS has a lifetime of $\sim 6$ days based on a $24 \mathrm{~h}[\mathrm{OH}]$ of $1 \times 10^{5}$ molecules $\mathrm{cm}^{-3}$ at $260 \mathrm{~K}$ ). The measurements made by Preunkert et al., 2007 at DDU report constant average values of between $13 \mathrm{pptV}$ in 2001 and $16 \mathrm{pptV}$ in 2002 for June-October which are lower than those observed at Halley. Peaks in October and late November of up to $175 \mathrm{pptV}$ are harder to attribute to exact sources, however at these times the wind speed around the continent reached $20 \mathrm{~m} / \mathrm{s}$ (Jones et al., 2008), which is expected to enhance sea-air flux of this species from local areas of open water in addition to increasing the rate of transport from further north.

\subsection{Ions}

The seasonal variations of the ions are shown in Fig. 2 and mean concentrations for the ions from this experiment are detailed within Table 1 which also shows averages for the same ions in 2001 (Rankin and Wolff, 2003).

Sodium $\left(\mathrm{Na}^{+}\right.$, a measure of sea salt) concentrations measured during CHABLIS were much more in-line with values

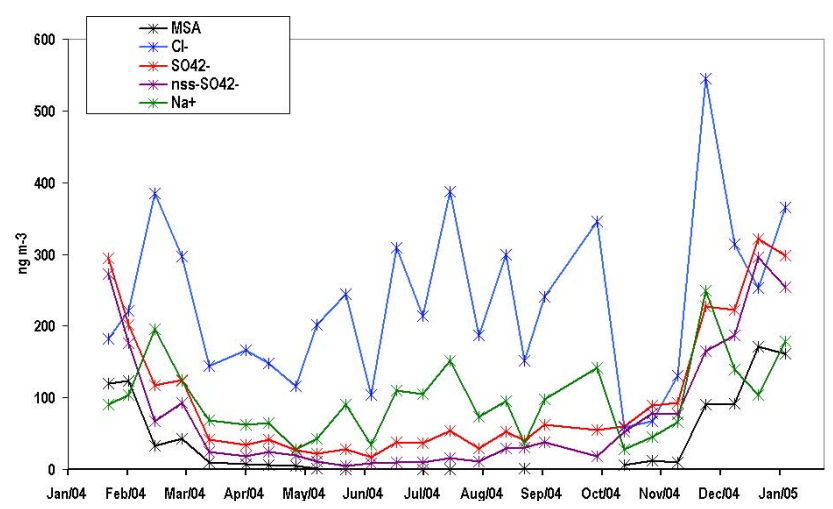

Fig. 2. Time-series of dimethyl sulphide (DMS), and bromine oxide (BrO) for February 2004-February 2005

reported for Halley between the years 1991-1993 by Wagenbach et al. (1998) $\left(62 \mathrm{ng} \mathrm{m}^{-3} \mathrm{Na}^{+}, 200 \mathrm{ng} \mathrm{m}^{-3}\right.$ total salt) rather than with the 2001 study which saw a mean value of over a factor of two higher. As stated within the 2001 study, aerosol concentrations are highly variable which leads to large interannual variability in the measurements and it was thought that the 2001 study was characterised by an isolated air mass depositing an unusually high loading of these species onto only one set of filters (Rankin and Wolff, 2003).

MSA was generally low throughout the year, showing an average of $42 \mathrm{ng} \mathrm{m}^{-3}(9.8 \pm 13.2 \mathrm{pptV})$, significantly lower than the $84 \mathrm{ng} \mathrm{m}^{-3}$ measured by Rankin and Wolff in 2001 but similar to a study by Minikin in 1998 in which three Antarctic sites (Neumayer, Dumont d'Urville, Halley) were compared and Halley (data from 1991-1992) was shown to display the lowest values for this species of $3.5 \mathrm{pptV}$ $\left(15 \mathrm{ng} \mathrm{m}^{-3}\right)$ (Minikin et al., 1998).

$\mathrm{Cl}^{-}$was present in similar average concentrations during both the 2001 and 2004/2005 experiments but also showed some interannual variability between January-February 2004 and January-February 2005 averaging $161 \mathrm{ng} \mathrm{m}^{-3}$ and $311 \mathrm{ng} \mathrm{m}^{-3}$, respectively. It showed a high variability throughout the year peaking in spring and then again in early summer with total fraction values rarely dropping below $100 \mathrm{ng} \mathrm{m}^{-3}$ (Fig. 2). Along with $\mathrm{Na}^{+}$, the $\mathrm{Cl}^{-}$ion was most dominant on the larger size fractions whereas ions such as MSA and $\mathrm{SO}_{4}^{2-}$, formed from gas phase species such as DMS were observed within the submicron fraction (Fig. 3). This was typical behaviour for these latter species although in contrast to previous studies the majority of the MSA and $\mathrm{SO}_{4}^{2-}$ was found in the $<0.25 \mu \mathrm{m}$ mode rather than in the $0.3 \mu \mathrm{m}$ (Jourdain and Legrand, 2002; Rankin and Wolff, 2003).

Sulphate $\left(\mathrm{SO}_{4}^{2-}\right)$ was also present from sea salt. Equation (1) below can be used to provide a derived quantity nonsea-salt sulphate as an indicator of biogenic activity.

$$
\left[\mathrm{nss}-\mathrm{SO}_{4}^{2-}\right]=\left[\mathrm{SO}_{4}^{2-}\right]_{\text {total }}-k\left[\mathrm{Na}^{+}\right]
$$


Here $k$ is equal to 0.252 , the weight ratio between sulphate and sodium in seawater (Wagenbach et al., 1998). There has been discussion as to whether a lower ratio should be used to account for the finding that sea ice surfaces, with a lower sulfate/Na ratio, act as a source of sea salt (Wagenbach et al., 1998); however, the difference does not affect the main results of this paper. The calculated nss- $\mathrm{SO}_{4}^{2-}$ is also plotted on Fig. 2.

\subsection{DMS, $\mathrm{BrO}, \mathrm{MSA}$ and nss- $\mathrm{SO}_{4}{ }^{2-}$ seasonal variation}

During the CHABLIS experiment MSA particulate and the derived nss- $\mathrm{SO}_{4}{ }^{2-}$ concentrations peak in late January until early February and then drop off very sharply when the DMS mixing ratios peak in late February-early March (Figs. 1 and 2). This rapid decrease in mixing ratios at the end of austral summer was also observed in a study by Prospero et al. (1991) and implies perhaps that the process responsible for converting DMS into MSA is less efficient at this time. Regression analysis highlights no correlation between DMS and the two particulates $\left(R^{2}=0.039\right.$, and $R^{2}=0.001$ for MSA and derived nss-SO ${ }_{4}{ }^{2-}$ respectively) throughout the year. The background mixing ratios in DMS throughout winter were also not mirrored by the MSA concentrations, a finding similar to that of Jourdain et al. (2001), who attributed the winter DMS to either small emissions from open water present in sea ice located offshore and/or advection from further north in conjunction with a longer lifetime of DMS (Jourdain and Legrand, 2001). Davison et al. (1996), on a cruise between the UK and the Antarctic, observed poor regression $\left(R^{2}=0.3\right)$ between DMS and MSA measurements even though in that study measurements appeared to coincide. In this study the poor correlation is thought to be a consequence of either that a) the DMS observed at Halley is emitted from the Weddell Sea region but the MSA is a result of processing of DMS emitted from areas substantially further north or b) that emissions vary little throughout the summer months (December-March). Levels of oxidants such as $\mathrm{OH}$ and $\mathrm{BrO}$ measured at the site show little month to month variation with respect to the 1 sigma standard deviations on the average measurements (January, $0.018 \pm 0.013 \mathrm{pptV}$ and $1.9 \pm 3.0 \mathrm{pptV}$ respectively compared to February, $0.015 \pm 0.009 \mathrm{pptV}$ and $2.7 \pm 2.2 \mathrm{pptV}$ respectively), however these are local measurements and may not be representative of the oxidant levels along the back trajectory of the air mass. $\mathrm{BrO}$ measurements show a seasonal cycle which peaks in austral Spring coinciding with the onset of sunlight and the lowest DMS measurements. Refer to Saiz Lopez et al. (2007) for more discussion of the BrO measurements including their seasonal variation.

Both DMS and MSA show some interannual variability between the summer months. DMS mixing ratios collected from 1 to 8 February 2005 averaged $31 \pm 10 \mathrm{pptV}$, significantly lower than the average for the same period in 2004 of $136 \pm 59 \mathrm{pptV}$. Measurements were fin-

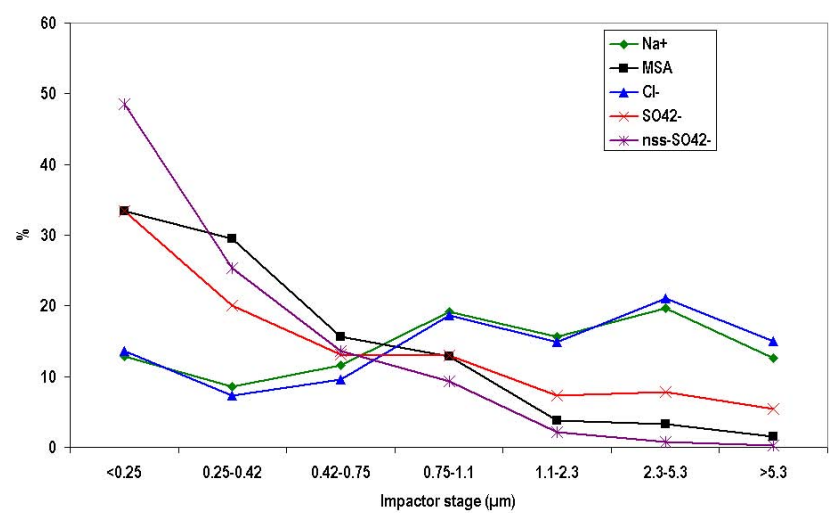

Fig. 3. Distribution of ions between stages.

ished on 8 February 2005 and so it remains unknown as to whether the levels would increase throughout the month and into March as in the previous year. MSA also shows some interannual variability between the two summers averaging $19.4 \pm 15.6 \mathrm{pptV}\left(83.2 \mathrm{ng} \mathrm{m}^{-3}\right)$ in JanuaryFebruary 2004 and $33.0 \pm 10.2 \mathrm{pptV}\left(141.3 \mathrm{ng} \mathrm{m}^{-3}\right)$ in January-February 2005. Interannual variability has been observed many times before with these types of measurements and in experiments which span two summers, for example Minikin et al. (1998) observed MSA concentrations of $1.3 \pm 1.7 \mathrm{pptV}\left(5.5 \pm 7.2 \mathrm{ng} \mathrm{m}^{-3}\right)$ and $5.1 \pm 6.3 \mathrm{pptV}$ $\left(21.9 \pm 26.9 \mathrm{ng} \mathrm{m}^{-3}\right)$ for December 1991 and December 1992 respectively and $3.0 \pm 2.1 \mathrm{pptV}\left(13.0 \pm 8.9 \mathrm{ng} \mathrm{m}^{-3}\right)$ and $12.5 \pm 9.6 \mathrm{pptV}\left(53.6 \pm 41.3 \mathrm{ng} \mathrm{m}^{-3}\right)$ for the subsequent January 1992 and 1993.

\section{Factors affecting DMS and MSA measurements and their interannual variability}

Although Halley is ideally situated on the ice shelf in close proximity to the Weddell Sea, a number of conditions exist which will affect the DMS mixing ratios measured at the CASLab. These will include physical, meteorological, and chemical factors. A consequence of the varying conditions is that it is difficult to compare measurements from different sites and/or from ships; and interannual variability also arises as a result of these factors.

Extensive ice cover during most of the year minimises gas exchange between seawater and the overlying atmosphere. Variability in the extent of cover spatially, affects both local mixing ratios for these species and accounts for a large majority of the year to year interannual variability of DMS observed in this region of the atmosphere (Cosme et al., 2005). During February 2004-February 2005 the sea ice cover was at a minimum during March 2004 in-line with the highest measured DMS mixing ratios. In agreement with the Prospero et al. (1991) study the particulate MSA and derived nss-SO ${ }_{4}{ }^{2-}$ measurements from CHABLIS are less strongly 

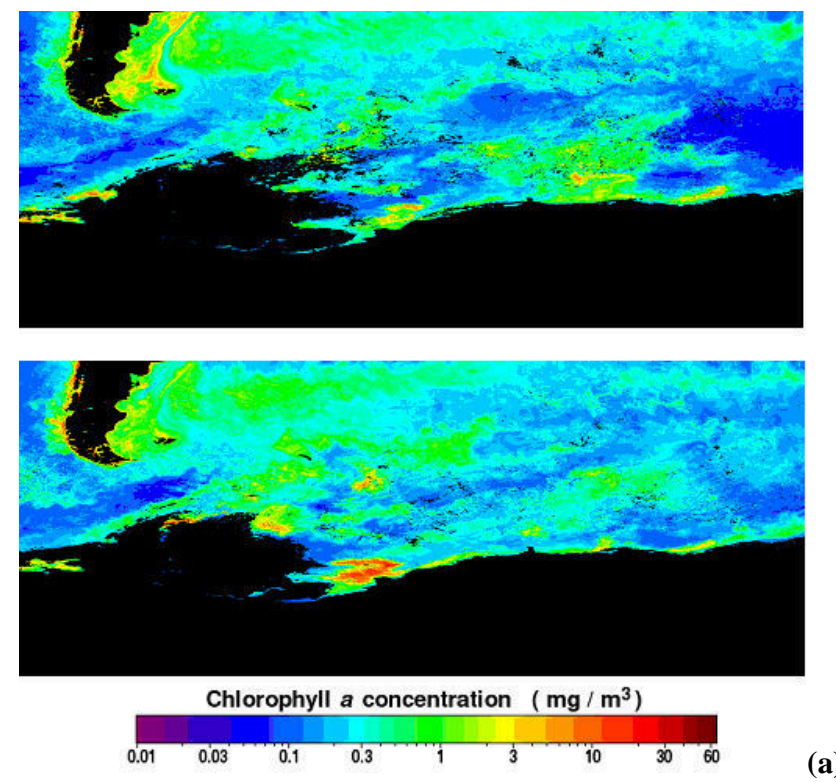

(a)
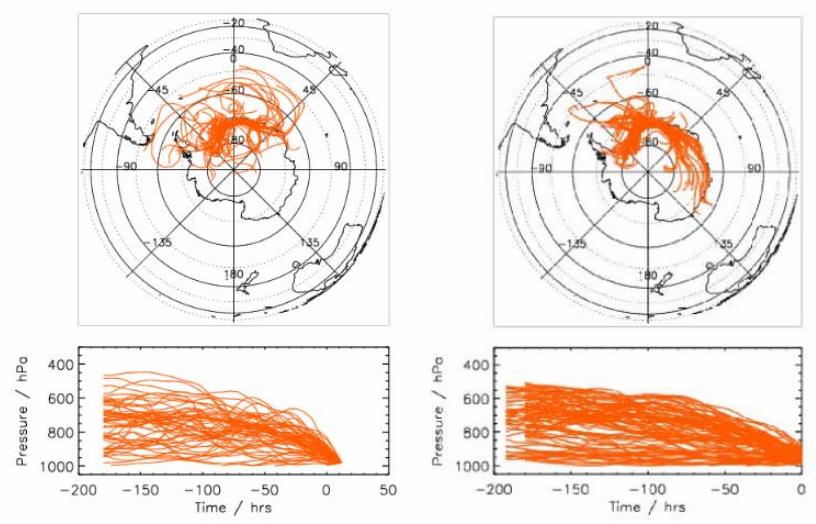

(b)

Fig. 4. (a) Spatial distribution of chlorophyll for winter 2004 above and winter 2005 below from http://seawifs.gsfc.nasa.gov/ and (b). 8-day air mass back trajectories for winter 2004 (left) and winter 2005 (right).

correlated with the sea ice cover showing sharply decreasing concentrations during this time of the year.

If the sea-ice conditions are favourable for DMS emissions, there still has to be a sufficient distribution and quantity of phytoplankton present in the sea water within the exposed areas. Studies have shown that phytoplankton blooms are often associated with sea ice retreat, shallow waters, with areas of strong upwelling and regions of high eddy kinetic energy; conditions prevalent in the Weddell Sea region (Comisco et al., 1993). Figure 4a shows chlorophyll data, (an indicator of phytoplankton blooms) from seawifs satellite data (http://seawifs.gsfc.nasa.gov/) for austral winter 2004 and 2005 which highlights variability in both the chlorophyll and the sea ice cover from year to year. It is impossible to identify whether these variations are the reason for the in- terannual variability in the DMS mixing ratios without additionally considering the air mass origins. Additional complications arise from the fact that different species of phytoplankton have different abilities to produce DMS. Following from this Fig. 4b shows that there were far fewer directly advected air masses from ocean sectors which had passed over highly-concentrated-chlorophyll regions during the second year. Southwest of the site is Precious Bay, an area which often has open water even in winter, and during winter peaks in DMS corresponded to these air masses or occurred during small low pressure storms in which there were higher temperatures experienced at the site. During the SCATE campaign low pressure storm systems were also shown to be a transport mechanism for DMS within the free troposphere influencing the concentrations of its oxidation products by downward mixing (Berresheim and Eisele, 1998). Unfortunately due to technical difficulties DMS data was not obtained during the major low pressure storm which occurred in May 2004 during this campaign (Jones et al., 2007).

Finally en route to the site there must also be the right chemical conditions to a) allow DMS to be transported without oxidation in order to measure DMS and/or to b) allow oxidation to DMSO and then to MSA for MSA to be measured on the filters. These conditions include the various oxidant concentrations and distribution and will impact on the lifetime and concentration of both DMS and therefore its oxidation products.

\subsection{Oxidation of DMS by $\mathrm{OH}$}

Much focus has in the past been on the reaction of $\mathrm{DMS}+\mathrm{OH}$ as the primary oxidation route for this species (Berresheim et al., 1998b; Jourdain and Legrand, 2001; Legrand et al., 2001), particularly with respect to the production of DMSO. The DMSO can then be oxidised further to produce either MSA or nss- $\mathrm{SO}_{4}^{2-}$, and it is these oxidised products which can be found in ice cores and used as indicators of air origin.

The reaction of DMS+OH proceeds via two independent channels (Hynes et al., 1986).

$\mathrm{OH}+\mathrm{CH}_{3} \mathrm{SCH}_{3} \rightarrow \mathrm{CH}_{3} \mathrm{SCH}_{2}+\mathrm{H}_{2} \mathrm{O}$ (abstraction)

$k_{1}(265 \mathrm{~K})=4.50 \times 10^{-12} \mathrm{~cm}^{3}$ molecule $\mathrm{e}^{-1} \mathrm{~s}^{-1}$

$\mathrm{OH}+\mathrm{CH}_{3} \mathrm{SCH}_{3} \rightarrow \mathrm{CH}_{3} \mathrm{~S}(\mathrm{OH}) \mathrm{CH}_{3}$ (addition)
$k_{2}(265 \mathrm{~K})=2.21 \times 10^{-11} \mathrm{~cm}^{3}$ molecule $\mathrm{s}^{-1}$

The addition channel leads to $\mathrm{CH}_{3} \mathrm{~S}(\mathrm{OH}) \mathrm{CH}_{3}$ or DMSO and subsequently to a greater relative production of MSA rather than nss- $\mathrm{SO}_{4}{ }^{2-}$, as compared to the abstraction channel (Fig. 5). An alternative route for the production of MSA exists via the abstraction channel but it 


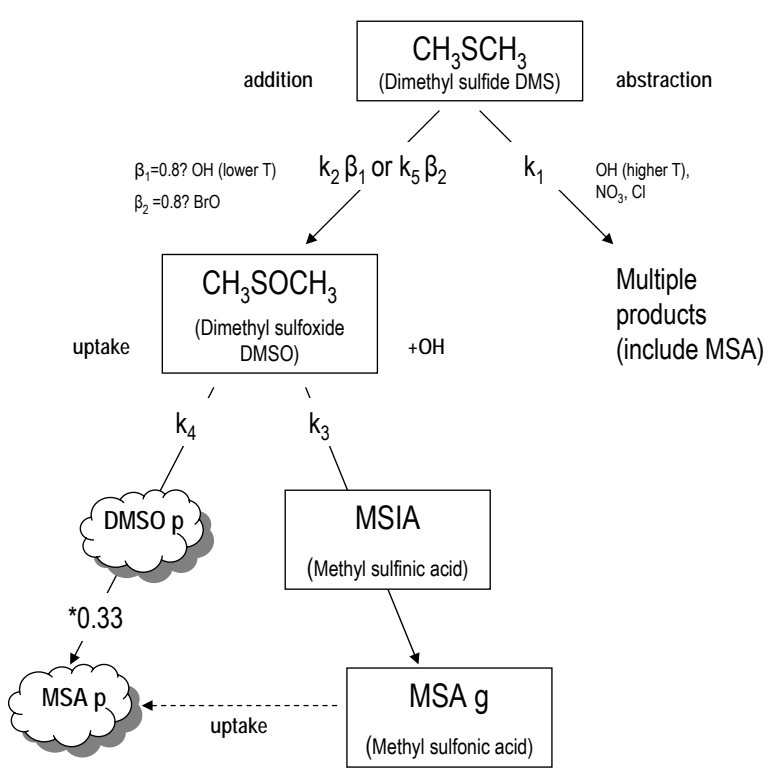

Fig. 5. Simplified schematic of DMS oxidation chemistry.

is a much more complex route involving $\mathrm{NO}_{2}$ chemistry (Von Glasow et al., 2004) which considering that in the Antarctic environment $\mathrm{NO}_{2}$ mixing ratios are typically $<15 \mathrm{pptV}$, this is considered a negligible source of MSA.

The MSA:nss- $\mathrm{SO}_{4}{ }^{2-}$ ratio, $R$ (Legrand and Pasteur, 1998) can provide much information as to the oxidation pathways of DMS, although care must be taken to interpret the various contributions to the nss- $\mathrm{SO}_{4}{ }^{2-}$ concentrations from nonDMS sources such as sulphate from continental areas and downward transport from the stratosphere. Using ${ }^{210} \mathrm{~Pb}$ levels Minikin et al. (1998) reported values for the FT non-DMS sulphate for coastal Antarctica of $15( \pm 5) \mathrm{ng} \mathrm{m}^{-3}$ for MarchSeptember, and $27( \pm 13) \mathrm{ng} \mathrm{m}^{-3}$ for October-February, which can be subtracted from the nss- $\mathrm{SO}_{4}{ }^{2-}$ concentration before calculation of the ratio. This gives $\mathrm{R}_{b}$ which can subsequently be compared to literature and interpreted with respect to DMS oxidation. MSA:nss- $\mathrm{SO}_{4}{ }^{2-}$ ratios are shown in Fig. 6 along with $R_{b}$. During January-February 2004 and 2005 the average $R_{b}$ of $0.65 \pm 0.13$ was higher than the peak value for Halley of $0.49 \pm 0.05$ reported for January 1992 and also substantially higher than the annual peak values of $0.46 \pm 0.17$ (Neumeyer, January 1983-1995) and of 0.28 \pm 0.05 (Dumont d'Urville, March 1983-1995) (Legrand and Pasteur, 1998), implying a dominance in the addition pathway for these measurements of DMS at Halley. In addition it is commonly thought that the addition channel is faster at low temperatures $(<285 \mathrm{~K})$ (Arsene et al., 1999) which could explain the higher ratios observed in this study.

If we want to investigate the MSA production from DMS then we must consider the addition route to DMSO. If we first assume that the concentration of DMSO in the atmosphere is controlled by a) production via the $\mathrm{DMS} / \mathrm{OH}$ pathway, b) reaction with $\mathrm{OH}$ in the gas phase $\left(k_{3}=1 \times 10^{-10} \mathrm{~s}^{-1}\right.$

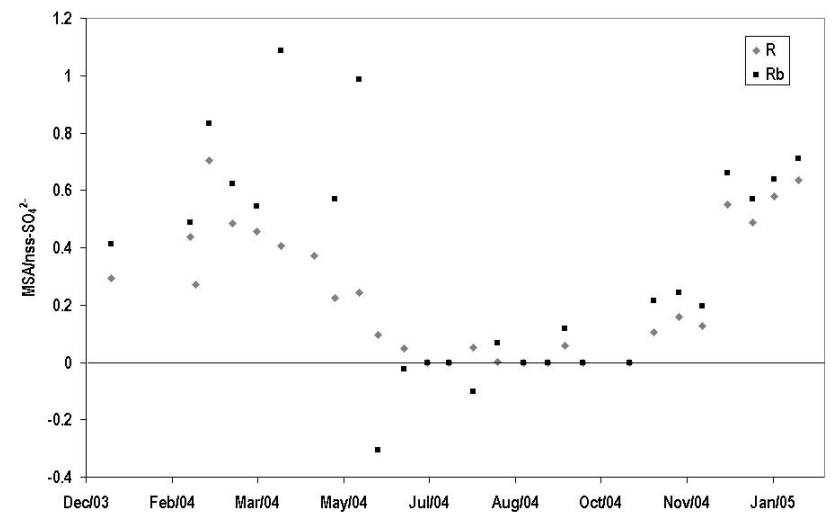

Fig. 6. MSA: nss- $\mathrm{SO}_{4}{ }^{2-}$ ratios $R$ and $R_{b}$ which includes an adjustment to the nss- $\mathrm{SO}_{4}{ }^{2-}$ for a non-DMS contribution of $15 \pm 5 \mathrm{ng} \mathrm{m}^{-3}$ in winter and $27 \pm 13 \mathrm{ng} \mathrm{m}^{-3}$ in summer, (see text) calculated from cascade impactor filter measurements during CHABLIS. Error bars for $R_{b}$ are also marked.

Hynes and Wine, 1996), and c) loss onto aerosols, we can calculate [DMSO] by knowing the yield $\left(\beta_{1}\right)$ of the $\mathrm{DMS}+\mathrm{OH}$ reaction, together with $k_{4}$, the heterogeneous loss rate of DMSO.

For this analysis we are focussing on the summer (December-March) measurements of DMS and MSA and the apparent interannual variability between 2004 and 2005. We have used a yield $\left(\beta_{1}\right)$ of DMSO from the DMS+OH reaction of 0.8 (Legrand et al., 2001) and the value for heterogeneous loss of DMSO was taken from a kinetic study by Bardouki et al. (2002) $\left(k_{4}=2.25 \times 10^{-4} \mathrm{~s}^{-1}\right)$. DMSO is not thought to be directly emitted from the oceans and no consideration has so far been given to the impact of other oxidants such as $\mathrm{Cl}$, and $\mathrm{NO}_{3}$ on the concentration of DMSO, because the reaction with these species is at least 2 orders of magnitude slower than with OH (Falbe-Hansen, 2000).

The following equation Eq. (2) can be used to obtain a time dependent level of DMSO using the measured DMS mixing ratios in this study. $\mathrm{OH}$ measurements only began in December 2004-February 2005 and so the average measured $24 \mathrm{~h}$ value of $3.9 \times 10^{5}$ molecules $\mathrm{cm}^{-3}(0.012 \mathrm{pptV})$ (Bloss et al., 2007) was used for the analysis of both summers. Previous measurements made eleven years earlier show values in good agreement for February (Jefferson et al., 1998). Calculations were initiated applying an initial level of DMSO of $3 \mathrm{pptV}$ (average measured concentration Legrand et al., 2001) and actual DMS mixing ratios were inputted when they were available, usually every hour.

$d[\mathrm{DMSO}] / d t=\beta_{1} k_{2}[\mathrm{DMS}][\mathrm{OH}]-\left(k_{3}[\mathrm{OH}]+k_{4}\right)[\mathrm{DMSO}]$ 

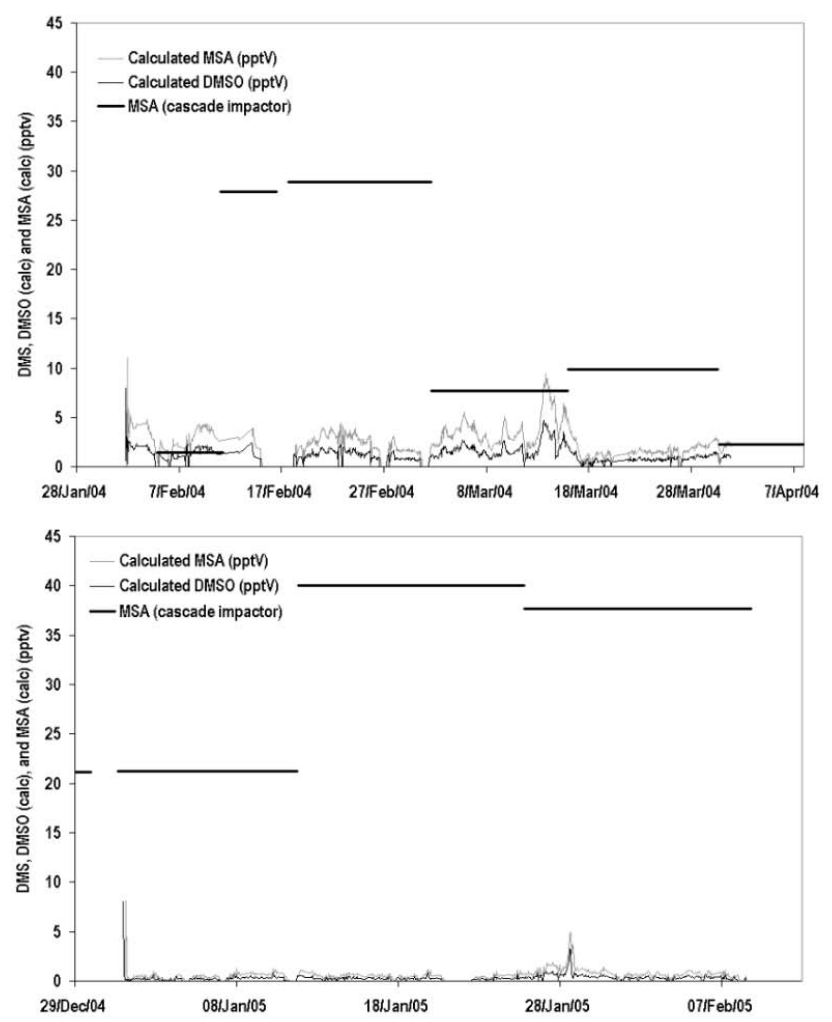

Fig. 7. Measured MSA and calculated MSA and DMSO mixing ratios for Feb-Mar 2004 (above) and Jan-Feb 2005 (below).

Roughly one third of the DMSO (DMSOp) produced is thought to be rapidly oxidised into MSA aerosol via MSIA (Legrand et al., 2001), as in Eq. (3).

$[\mathrm{MSA}]=0.33 k_{4}\left[\mathrm{DMSO}_{p}\right] \Delta t$

$\Delta t$ had to be assumed and so $4 \mathrm{~h}$ was used based on calculations from Jourdain and Legrand (2001). This assumption obviously leads to potential errors in the calculation of absolute MSA however the importance of this work is to demonstrate the impact of the additional oxidation routes not solely to reproduce the absolute concentrations of MSA.

The calculated MSA mixing ratios are plotted on Fig. 7 together with the measured cascade impactor sample mixing ratios of MSA.

Looking first at the 2004 data, there is reasonable agreement in mid-February but there is an underestimation in the calculated [MSA] during early and late February. The DMS and MSA show different trends through this period implying that the DMS measured at the site is not wholly responsible for the measured [MSA]. The DMS is likely to have originated from fresh emissions rather than having been transported, whilst the MSA may have been transported from further afield. This is in line with the air mass trajectories for this time which show much of the air has travelled over the Weddell Sea region (Fig. 4b). Note: the calculation of
Table 2. The reaction rate coefficients of DMS with $\mathrm{OH}, \mathrm{Cl}, \mathrm{BrO}$, $\mathrm{IO}, \mathrm{O}_{3}$ and $\mathrm{NO}_{3}$.

\begin{tabular}{lll}
\hline DMS+... & $\begin{array}{l}T=260 \mathrm{~K} \\
\left(\mathrm{~cm}^{3} \text { molecule } \mathrm{s}^{-1}\right)\end{array}$ & $\begin{array}{l}\text { Estimated lifetime } \\
(\text { days })\end{array}$ \\
\hline $\mathrm{OH}$ & $2 \times 10^{-11}$ & $1.5^{\mathrm{a}}$ \\
$\mathrm{Cl}$ & $3.3 \times 10^{-10}$ & $3.5^{\mathrm{b}}$ \\
$\mathrm{BrO}$ & $3.94 \times 10^{-13}$ & $0.4^{\mathrm{c}}$ \\
$\mathrm{IO}$ & $1.3 \times 10^{-14}$ & $12.03^{\mathrm{d}}$ \\
$\mathrm{O}_{3}$ & $<1 \times 10^{-18}$ & $>31^{\mathrm{e}}$ \\
$\mathrm{NO}_{3}$ & $f 1.5-7 \times 10^{-12}$ & $-\mathrm{g}$ \\
\hline
\end{tabular}

Kinetic data from Atkinson et al., 2004.

a $\mathrm{OH}$ assuming a $24 \mathrm{~h}$ average of $3.9 \times 10^{5}$ molecule $\mathrm{cm}^{-3}$ measured during January-February 2005 (Bloss et al., 2007).

$\mathrm{b}$ Maximum concentration of 104 atom $\mathrm{cm}^{-3}$ during August (Read et al., 2007).

c average concentration of $3 \mathrm{pptV}$ during January-March (SaizLopez et al., 2007).

$\mathrm{d}$ average concentration of $3 \mathrm{pptV}$ during January-March (SaizLopez et al., 2007).

e $24 \mathrm{~h}$ average ozone $15 \mathrm{ppbV}$.

${ }^{\mathrm{f}} \mathrm{Ab}$ initio data from Jee and Tao, 2006.

g $\mathrm{NO}_{3}<2$ pptV detection limit (Jones et al., 2007).

[DMSO] and [MSA] is based on the varying concentration of DMS measured at Halley, not its value at the point of emission.

During January-February 2005 DMS mixing ratios were much lower and there is substantial underestimation by the calculated [MSA] when compared to the measured [MSA]. The air mass trajectories show more air has travelled over the continent in 2005 rather than from the northern sea regions (Fig. 4b) implying that the site received more aged air and had fewer fresh emission injections; so the DMS mixing ratios measured at the site may not be representative of those at the source. Underestimation of the calculated MSA implies either that the $\mathrm{OH}$ and/or DMS mixing ratios we have used in our calculations are too low, that additional oxidation routes other than that of $\mathrm{OH}+\mathrm{DMS}$ are responsible for the MSA production, or that the $\Delta \mathrm{t}$ we have used is too low.

\subsection{Impact of $\mathrm{BrO}$ mixing ratios on the oxidation of DMS}

Reaction rate coefficients for DMS with species other than $\mathrm{OH}$ are detailed in Table 2. The obvious competitor to $\mathrm{OH}$ is $\mathrm{NO}_{3}$ but during the whole of CHABLIS it was not seen to be above the instrumental detection limit of the LP-DOAS instrument $(2 \mathrm{pptV})$. BrO however was measurable in mixing ratios up to $8 \mathrm{pptV}$ in summer which, when considered in context with a rapid rate of DMS+BrO, represents a significant sink for DMS. IO measurements were also made and found to be present in the atmosphere in similar mixing ratios as those of $\mathrm{BrO}$, however IO reacts more slowly 
Table 3. Factor increase in calculated MSA compared to the $\mathrm{BrO}=0 \mathrm{ppt} \mathrm{V}$ case whilst assuming constant yields of 0.8 and constant $\mathrm{OH}=0.012 \mathrm{pptV}$ but changing $\mathrm{BrO}$.

\begin{tabular}{cc}
\hline $\begin{array}{c}\text { Concentration } \\
(\mathrm{pptV})\end{array}$ & $\begin{array}{c}\text { Factor increase in calculated MSA } \\
\text { (Assuming constant yield of } \beta_{1} \\
\text { and } \beta_{2}=0.8 \text { and constant OH of } 0.012 \mathrm{pptV} . \\
\text { The base case is BrO=0 pptV reaction.) }\end{array}$ \\
\hline 0 & 1 \\
1 & 3.68 \\
2 & 6.36 \\
3 & 9.02 \\
4 & 11.7 \\
5 & 14.4 \\
6 & 17.1 \\
7 & 19.8 \\
\hline
\end{tabular}

than $\mathrm{BrO}$ with DMS (Table 2). $\mathrm{Cl}$ atoms were not measured directly but inferred from non-methane hydrocarbons and found to be at a maximum of $3.4 \times 10^{4}$ atom $\mathrm{cm}^{-3}$ during spring (Read et al., 2007). $\mathrm{Cl}$ is likely to be at least a factor of 5 lower during summer, and therefore the loss of DMS through reaction with $\mathrm{Cl}$ is likely to be less than $20 \%$ of that through reaction with $\mathrm{BrO}$ during summer.

Von Glasow et al. (2004) showed that including halogen chemistry and specifically $\mathrm{BrO}$ into atmospheric chemistry transport models, led to an increase of 63\% DMSO globally. Barnes et al. (1991) found that BrO also adds to DMS which has a major impact on our $\mathrm{OH}$ dominated calculations for MSA and could account for the high MSA:nss- $\mathrm{SO}_{4}{ }^{2-}$ ratios (Fig. 6). It could also explain the underestimation in the calculated [MSA] versus measured [MSA] and, assuming variable levels, the lack of correlation between our atmospheric DMS and particulate MSA. A study by Gondwe et al. (2004) which compares modelled MSA:nss- $\mathrm{SO}_{4}{ }^{2-}$ ratios with measured, underestimates the ratio for measurements made in the Southern Ocean and Drake Passage. Although this modelling study was fairly crude, higher measured ratios compared to model predictions such as these which neglect to include $\mathrm{BrO}$, may also imply an influence from this source.

We can include the reaction of $\mathrm{BrO}+\mathrm{DMS}$ into our time dependent DMSO equation to give the following:

$$
\begin{aligned}
& d[\mathrm{DMSO}] / d t=\left(\beta_{1} k_{2}[\mathrm{DMS}][\mathrm{OH}]+\beta_{2} k_{5}[\mathrm{DMS}][\mathrm{BrO}]\right) \\
& -\left(k_{3}[\mathrm{OH}]+k_{4}\right)[\mathrm{DMSO}],
\end{aligned}
$$

We have used measured BrO mixing ratios for the two summer periods (Saiz-Lopez et al., 2007) whilst the $\mathrm{OH}$ concentration is as we treated before, set at $3.9 \times 10^{5}$ molecules $\mathrm{cm}^{-3}$ (Bloss et al., 2007) as this was the average of measurements throughout the 2005 summer months. Using an estimated yield $\left(\beta_{2}\right)$ of 0.8 , the exact yield not yet having been determined (Toumi, 1994), the DMSO and resultant MSA concentration increase on average by a factor of 9 (Table 3).
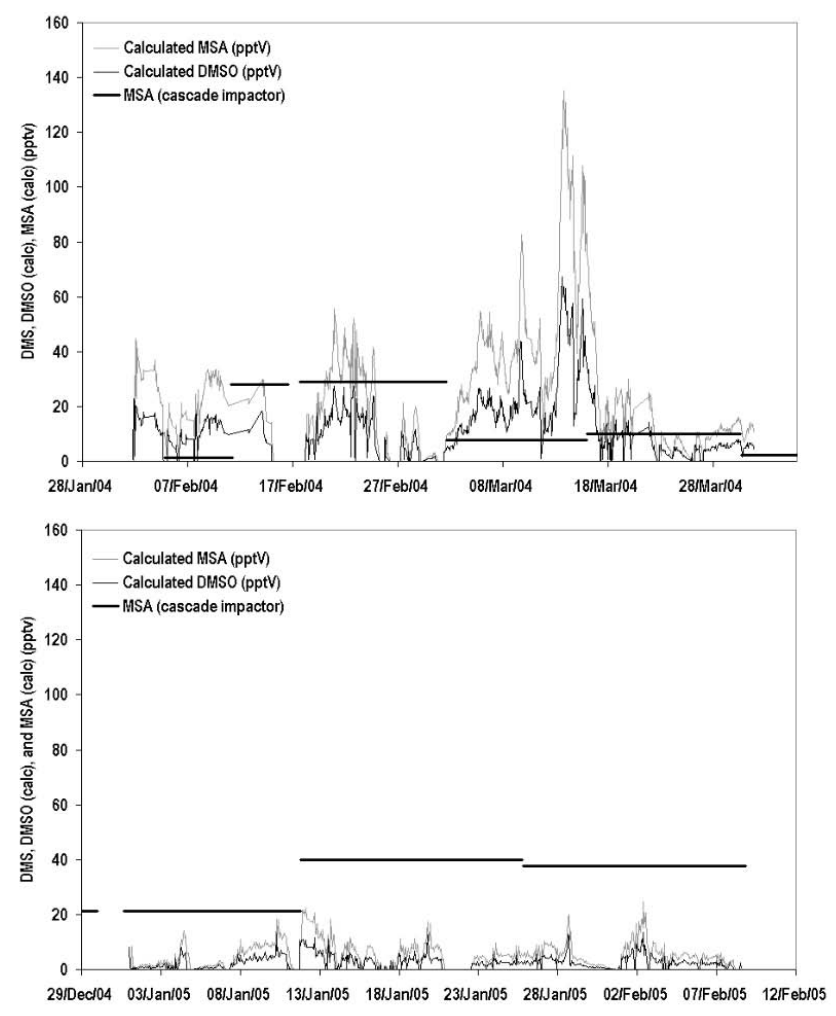

Fig. 8. Measured MSA and calculated MSA and DMSO mixing ratios for February-March 2004 (above) and January-February 2005 (below) including the contribution from $\mathrm{BrO}$ reactions.

Although measurements of $\mathrm{BrO}$ were used for this study, they are locally measured levels and so may not be representative of the mixing ratios of this species at the time of DMS oxidation. Due to the nature of its sources and sinks the atmospheric $\mathrm{BrO}$ concentration is likely to be more variable than that of the $\mathrm{OH}$ and so the sensitivity of the analysis to changing $\mathrm{BrO}$ has also been calculated and is also detailed in Table 3 .

With the inclusion of the DMS+BrO reaction, the calculated MSA during most of February-March 2004 are now in better agreement with the measured (Fig. 8). As expected the calculated MSA in early March now overestimates the measured MSA, in-line with the assumption that the DMS and MSA measurements are not directly related at this time and this period is influenced by fresh emissions. During JanuaryFebruary 2005 however, there is still some underestimation. This implies that the DMS mixing ratios measured at the site are not representative of the emissions at source or that the time allowed for the build-up of the DMSO on the aerosol is too short. The measured MSA mixing ratios are relatively high ( $\sim 40 \mathrm{pptV})$ however which is consistent with assumptions that the DMS has had time to oxidise en route and it is clear from this analysis that the DMS+BrO reaction is important in its oxidation. 
Table 4. Factor increase in calculated MSA whilst assuming a constant $\mathrm{BrO}$ and $\mathrm{OH}$ but changing yields.

\begin{tabular}{lll}
\hline Yield ( $\beta_{1}$ or $\beta_{2}$ respectively) & $\begin{array}{l}\text { Factor increase in calculated MSA } \\
\text { (assuming base case of constant } \mathrm{BrO}=3 \mathrm{pptV}, \\
\left.\mathrm{OH}=0.012 \mathrm{pptV} \text { and } \beta_{2}=0.8\right)\end{array}$ & $\begin{array}{l}\text { Factor increase in calculated MSA } \\
\text { (assuming base case of constant } \mathrm{BrO}=3 \mathrm{pptV}, \\
\left.\mathrm{OH}=0.012 \mathrm{pptV}, \text { and } \beta_{1}=0.8\right)\end{array}$ \\
\hline 0.4 & 0.945 & 0.583 \\
0.5 & 0.958 & 0.694 \\
0.6 & 0.972 & 0.805 \\
0.7 & 0.986 & 0.917 \\
0.8 & 1 & 1 \\
0.9 & 1.01 & 1.14 \\
1 & 1.03 & 1.25 \\
\hline
\end{tabular}

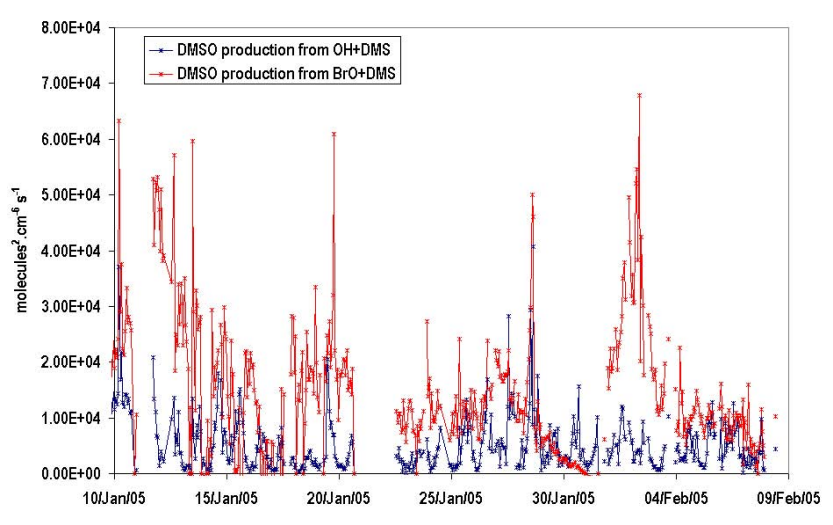

Fig. 9. Rate of production of DMSO from the reaction of DMS with $\mathrm{OH}$ and $\mathrm{BrO}$.

For the Summer 2005 period the relative rate of oxidation of DMS by $\mathrm{OH}$ and $\mathrm{BrO}$ is calculated using the measurements of DMS, BrO and $\mathrm{OH}$ when all three were measured simultaneously and this is shown in Fig. 9. The rate of oxidation of DMS by BrO dominates the DMS oxidation by on average a factor of 7 throughout the summer.

A change in the yield of either the $\mathrm{DMS}+\mathrm{BrO}$ reaction or the $\mathrm{DMS}+\mathrm{OH}$ reaction changes the factor increase in the DMSO and therefore in the MSA mixing ratios and so knowledge of the yields of these reactions is crucial to this analysis. Table 4 details the factor increase in MSA assuming $\mathrm{BrO}$ and $\mathrm{OH}$ at constant levels of $3 \mathrm{pptV}$ and $0.012 \mathrm{pptV}$ respectively with changing yields.

Assuming that the MSA from the abstraction route is negligible then this analysis shows that the MSA concentration is far more sensitive to the yield of $\mathrm{BrO}+\mathrm{DMS}$ rather than to the yield of $\mathrm{OH}+\mathrm{DMS}$.

\section{Implications of these findings}

Although low temperatures such as those experienced in the Antarctic can lead to a favoured addition route for the oxida- tion of DMS, it is more likely that the increased MSA production observed at Halley is a result of the presence of $\mathrm{BrO}$. $\mathrm{BrO}$ strongly increases the importance of the addition branch and indeed the oxidation rate even at low atmospheric mixing ratios. There is therefore a likely underestimation of the total oxidation rates of DMS in studies which do not incorporate halogen chemistry.

As highlighted in the work of Von Glasow et al. (2002), this finding also impacts on flux calculations as DMS from the ocean is often calculated based on atmospheric DMS mixing ratios and the assumption that reaction with $\mathrm{OH}$ is the only chemical loss. If $\mathrm{BrO}$ is a significant sink for DMS, the resulting DMS fluxes must be higher to yield the same atmospheric DMS mixing ratios.

\subsection{Ice core implications}

Both MSA and nss- $\mathrm{SO}_{4}{ }^{2-}$, as well as their ratio, have been used in ice core studies to try to diagnose environmental conditions in the past. In particular, MSA has been proposed as an indicator of sea ice extent (Curran et al., 2003; Abram et al., 2007), while there have been hopes that the ratio, if largely controlled by temperature, might yield information about the latitude and temperature history of sulphur emissions recorded in ice cores. If the presence of $\mathrm{BrO}$ can also play a substantial role in the relative and absolute production of MSA, then this raises a potential new complication in interpreting the ice core records of these species. In particular, we know that $\mathrm{BrO}$ is strongly associated with the presence of sea ice, although possibly strongly concentrated in the very lowest layers of the atmosphere (Simpson et al., 2007). If DMS remained in the volume of atmosphere strongly influenced by BrO for a substantial fraction of its lifetime, then this could provide a further mechanism for an influence of sea ice on MSA mixing ratios recorded in ice cores. Modelling studies (Cosme et al., 2005) for S compounds have not yet included a realistic assessment of $\mathrm{BrO}$, or its spatial and vertical distribution, which will be needed to determine whether $\mathrm{BrO}$ is really a major influence. 


\section{Conclusions}

A year-long (February 2004-February 2005) time-series of DMS measurements in the Antarctic troposphere has been presented along with aerosol filter measurements of its oxidation product MSA and also with derived nss- $\mathrm{SO}_{4}{ }^{2-}$. DMS shows a strong seasonal variation with an austral winter minimum and summer maximum which follows that of the seaice cover; but DMS was also observed to be present throughout the year due to its transport from biogenically active regions further north in association with an extended lifetime of 6 days under Antarctic conditions (assuming a $24 \mathrm{~h}$ average $\mathrm{OH}$ winter concentration of $1 \times 10^{5}$ molecules $\mathrm{cm}^{-3}$ ). The shorter-term variability in the DMS was found to be strongly due to air mass origin and trajectory pressure height. The biweekly $\mathrm{SO}_{4}^{2-}$, MSA and derived nss- $\mathrm{SO}_{4}{ }^{2-}$ filter data appears to correlate with the DMS data in that they show maximum values in summer and minimum in winter but in reality the data show very low regression values with DMS due to the infrequency and differences in sampling rates of the filter data, in addition to the various complexities in the rate of oxidation of DMS to form these products.

Using the DMS mixing ratios measured at the site in conjunction with recent kinetic data MSA mixing ratios were calculated and found at times to differ from the filter measurements. This was postulated to be due to a number of factors including the strong possibility of different DMS values at source (which may be 3.4 days away $\left(\mathrm{OH}=3.9 \times 10^{5}\right.$ molecules $\left.\mathrm{cm}^{-3}\right)$, and the influence of locally produced DMS on the site measurements. Chemical influences were also discussed including the additional effect of $\mathrm{BrO}$ on the production of DMSO and hence of MSA. Although the yield of the BrO+DMS reaction is still undetermined the impact of up to $7 \mathrm{pptV}$ of $\mathrm{BrO}$ on the calculated MSA atmospheric concentration was found to be highly significant, and will have a significant impact on model calculations for this region of the atmosphere.

Acknowledgements. The authors wish to thank NERC AFI for the CHABLIS funding under grant number NER/G/S/2001/00558 and to $\mathrm{S}$. Arnold for the calculation of the back trajectories.

Edited by: A. Jones

\section{References}

Abram, N. J., Mulvaney, R., Wolff, E. W., and Mudelsee, M.: Ice core records of sea ice variability in the Weddell Sea region of Antarctica, J. Geophys. Res., 112, D15101, doi:10.1029/2006JD008139, 2007.

Arsene, C., Barnes, I., and Becker, K. H.: FT-IR product study of the photo-oxidation of dimethyl sulfide: Temperature and $\mathrm{O}_{2}$ partial pressure dependence, Phys. Chem. Chem. Phys., 1, 54635470, 1999.

Atkinson, R., Baulch, D. L., Cox, R. A., Crowley, J. N., Hampson, R. F., Hynes., R. G., Jenkin, M. E., Rossi, M. J., and Troe, J.:
Evaluated kinetic and photochemical data for atmospheric chemistry: Volume 1 - gas phase reactions of Ox, HOx, NOx, and SOx species, Atmos. Chem. Phys., 4, 1461-1738, 2004, http://www.atmos-chem-phys.net/4/1461/2004/.

Ayers, G. P., Bentley, J. P., Ivey, J. P., and Forgan, B. W.: Dimethylsulphide in marine air at Cape Grim, $41^{\circ} \mathrm{S}$, J. Geophys. Res., 102, 21 013-21 021, 1995a.

Ayers, G. P., Cainey, J. M., Gillett, R. W., and Ivey, J. P.: Atmospheric sulphur and cloud condensation nuclei in marine air in the Southern Hemisphere, Phil. Trans. R. Soc. Lond. B, 352, 203-211, 1997.

Ayers, G. P., Gillett, R. W., Ivey, J. P., Schafer, B., and Gabric, A.: Short-term variability in marine atmospheric dimethyl sulphide concentration, Geophys. Res. Lett., 22, 2513-2516, 1995 b.

Bardouki, H., Barcellos da Rosa, M., Mihalopoulous, N., Palm, W.U., and Zetzsch, C.: Kinetics and mechanism of the oxidation of dimethylsulfoxide (DMSO) and methanesulfinate (MSI-) by $\mathrm{OH}$ radicals in aqueous medium, Atmos. Environ., 36, 4627-4634, 2002.

Barnes, I., Bastian, V., Becker, K. H., and Overath, R. D.: Kinetic studies of the reactions of $\mathrm{IO}, \mathrm{BrO}$, and $\mathrm{ClO}$ with DMS, Int. J. Chem. Kinet., 23, 579-591, 1991.

Berresheim, H.: Biogenic sulfur emissions from the Subantarctic and Antarctic Oceans, J. Geophys. Res., 92, 13 245-13 262, 1987.

Berresheim, H. and Eisele, F. L.: Sulfur Chemistry in the Antarctic Troposphere Experiment: An overview of project SCATE, J. Geophy. Res., 103, 1619-1627, 1998a.

Berresheim, H., Huey, J. W., Thorn, R. P., Eisele, F. L., Tanner, D. J., and Jefferson, A.: Measurements of dimethyl sulfide, dimethyl sulfoxide, dimethyl sulfone and aerosol ions at Palmer Station, Antarctica, J. Geophys. Res., 103, 1629-1637, 1998 b.

Bloss, W. J., Lee, J. D., Heard, D. E., Salmon, R. A., Bauguitte, S. J.-B., Roscoe, H. K., and Jones, A. E.: Observations of $\mathrm{OH}$ and $\mathrm{HO} 2$ radicals in coastal Antarctica, Atmos. Chem. Phys. Discuss., 7, 2893-2935, 2007,

http://www.atmos-chem-phys-discuss.net/7/2893/2007/.

Charlson, R. J., Lovelock, J. E., Andreae, M. O., and Warren, S. G.: Oceanic phytoplankton, atmospheric sulphur, cloud albedo and climate, Nature, 326, 655-661, 1987.

Comisco, J. C., McClain, R. C., Sullivan, C. W., Ryan, J. P., and Leonard, C. L.: Coastal Zone Color Scanner pigment concentrations in the Southern Ocean and relationships to geophysical surface features, J. Geophys. Res., 98, 2419-2451, 1993.

Cosme, E., Hourdin, F., Genthon, C., and Martinerie, P.: Origin of dimethyl sulfide, non-sea-salt sulfate, and methanesulfonic acid in eastern Antarctica, J. Geophys. Res., 110, D03302, doi:10.1029/2004JD004881, 2005.

Curran, M. A. J., van Ommen, T. D., Morgan, V. I., Phillips, K. L., and Palmer, A. S.: Ice core evidence for Antarctic sea ice decline since the 1950s, Science, 302, 1203-1206, 2003.

Davis, D. D., Eisele, F., Chen, G., Crawford, J., Huey, G., Tanner, D., Slusher, D., Mauldin, D., Oncley, S., Lenschow, D., Semmer, S., Shetter, R., Lefer, B., Arimoto, R., Hogan, A., Grube, P., Lazzara, M., Bandy, A., Thornton, D., Berresheim, H., Bingemer, H., Hutterli, M., McConnell, J., Bales, R., Dibb, J., Buhr, M., Park, J., McMurry, P., Swanson, A., Meinardi, S., and Blake, D.: An overview of ISCAT 2000, Atmos. Environ., 38, 5363-5373, 2004. 
Davison, B., Hewitt, C. N., O'Dowd, C. D., Lowe, J. A., Smith, M. H., Schwikowski, M., Baltensperger, U., and Harrison, R. M.: Dimethyl sulfide, methane sulfonic acid and physiochemical aerosol properties in Atlantic air from the United Kingdom to Halley Bay, J. Geophys. Res., 101, 22 855-22 867, 1996.

Davison, B., O'Dowd, C., Hewitt, C. N., Smith, M. H., Harrison, R. M., Peel, D. A., Wolff, E., Mulvaney, R., Schwikowski, M., and Baltensperger U.: Dimethyl sulfide and its oxidation products in the atmosphere of the Atlantic and Southern Oceans, Atmos. Environ., 30, 1895-1906, 1995.

Falbe Hansen, H., Sørensen, S., Jensen, N. R., Pedersen, T., Hjorth, J.: Atmospheric gas-phase reactions of diemthyl sulphoxide and dimethylsulphone with $\mathrm{OH}$ and $\mathrm{NO}_{3}$ radicals $\mathrm{Cl}$ atoms and ozone, Atmos. Environ., 34, 1543-1551, 2000.

Frieß, U., Hollwedel, J., Konig-Langlo, G., Wagner, T., and Platt, U.: Dynamics and chemistry of troposphieric bromine explosion events in the Antarctic coastal region, J. Geophys. Res., 109, D06305, doi:10.1029/2003JD004133, 2004.

Frieß, U., Kreher, K., Johston, P. V., and Platt, U.: Ground-based DOAS measurements of stratospheric trace gases at two Antarctic stations during the 2002 ozone hole period, J. Atmos. Sci., 63(3), 765-777, 2005.

Gondwe, M., Krol, M., Gieskes, W., Klaasen, W., and De Baar, H.: The contribution of ocean-leaving DMS to the global atmospheric burdens of DMS, MSA, $\mathrm{SO}_{2}$, and $\mathrm{NSS} \mathrm{SO}_{4}^{=}$, Global Biogeochem. Cy., 17, 2, 1056, doi:10.1029/2002GB001937, 2003.

Gondwe, M., Krol, M., Klassen, W., Gieskes, W., and De Baar, H.: Comparison of modeled versus measured MSA:nss SO42ratios: A global analysis, Global Biogeochem. Cy., 18, GB2006, doi:10.1029/2003GB002144, 2004.

Hegels, E., Crutzen, P. J., Klupfel, T., Perner, D., and Burrows, J. P.: Global distribution of atmospheric bromine-monoxide from GOME on earth observing satellite ERS-2, Geophys. Res. Lett., 25, 3127-3130, 1998.

Hynes, A. J., Wine, P. J., and Semmes, D. H.: Kinetics and mechanism of $\mathrm{OH}$ reactions with organic sulfides, J. Phys. Chem., 90, 4148-4156, 1986.

Hynes, A. J. and Wine, P. J.: The atmospheric chemistry of dimethyl sulfoxide (DMSO) kinetics and mechanism of the $\mathrm{OH}+\mathrm{DMSO}$ reaction, J. Atmos. Chem., 24, 23-27, 1996.

Ingham, T., Bauer, D., Sander, R., Crutzen, P. J., and Crowley, J. N.: Kinetics and products of the reactions $\mathrm{BrO}+\mathrm{DMS}$ and $\mathrm{Br}+$ DMS at 298K, J. Phys. Chem., 103, 7199-7209, 1999.

Jee J. and Tao, F. M.: Reaction mechanism and kinetics for the oxidation of dimethyl sufide by nitrate radical, Chem. Phys. Lett., 420, 336-339, 2006.

Jefferson, A., Tanner, D. J., Eisele, F. L., Davis, D. D., Chen, G., Crawford, J., Huey, J. W., Torres, A. L., and Berresheim, H.: $\mathrm{OH}$ photochemistry and methane sulfonic acid formation in the coastal Antarctic boundary layer, J. Geophys. Res., 103, 16471656, 1998.

Jones, A. E., Wolff, E. W., Salmon, R. A., Bauguitte, S. J.-B., Roscoe, H. K., Anderson, P. S., Ames, D., Clemitshaw, K. C., Fleming, Z. L., Bloss, W. J., Heard, D. E., Lee, J. D., Read, K. A., Hamer, P., Shallcross, D. E., Jackson, A., Walker, S., Lewis, A. C., Mills, G. P., Plane, J. M. C., Saiz-Lopez, A., Sturges, W. T., and Worton, D. R.: Chemistry of the antarctic boundary layer and the interface with snow: an overview of the CHABLIS campaign, Atmos. Chem. Phys. Discuss., 8, 5137-5181, 2008, http://www.atmos-chem-phys-discuss.net/8/5137/2008/.

Jourdain, B. and Legrand, M.: Seasonal variations of atmospheric dimethylsulfide, dimethylsulfoxide, sulfur dioxide, methanesulfonate, and non-sea-salt sulfate aerosols at Dumont d'Urville (coastal Antarctica) (December 1998 to July 1999), J. Geophys. Res., 106, 14 391-14 408, 2001.

Jourdain, B. and Legrand, M.: Year-round records of bulk and sizesegregated aerosol composition and $\mathrm{HCl}$ and $\mathrm{HNO}_{3}$ levels in the Dumont d'Urville (coastal Antarctica) atmosphere: Implications for sea-salt aerosol fractionation in the winter and summer, J. Geophys. Res., 107, 4645, 2002.

Kreher, K., Johnston, P. V., and Wood, S. W.: Ground-based measurements of tropospheric and stratospheric $\mathrm{BrO}$ at Arrival Heights, Antarctica, Geophys. Res. Lett., 24, 23, 3021-3024, 1997.

Legrand, M. and Pasteur, E. C.: Methane sulfonic acid to non seasalt sulfate ratio in coastal Antarctic aerosol and surface snow, J. Geophys. Res., 103(D9), 10 991-11 006, 1998.

Legrand, M., Sciare, J., Jourdain, B., and Genthon, C.: Subdaily variations of atmospheric dimethylsulfide, dimethylsulfoxide, methanesulfonate, and non-sea-salt sulfate aerosols in the atmospheric boundary layer at Dumont d'Urville (coastal Antarctica) during summer, J. Geophys. Res., 106, 14 409-14 422, 2001.

Liss, P. S., Hatton, A. D., Malin, G., Nightingale, P. D., and Turner, S. M.: Marine sulphur emissions, Philos. T. Roy. Soc. B, 352, 159-168, 1997.

Mauldin-III, R. L., Eisele, F. L., Tanner, D. J., Kosciuch, E., Shetter, R., Lefer, B., Hall, S. R., Nowak, J. B., Buhr, M., Chen, G., Wang, P., and Davis, D.: Measurements of $\mathrm{OH}, \mathrm{H}_{2} \mathrm{SO}_{4}$, and MSA at the South Pole during ISCAT, Geophys. Res. Lett., 28, 3629-3632, 2001.

Minikin,A., Legrand, M., Hall, J., Wagenbach, D., Kleefeld, C., Wolff, E., Pasteur, E. C., and Ducroz, F.: Sulfur containing species (sulfate and methanesulfonate) in coastal Antarctic aerosol and precipitation, J. Geophys. Res., 103, 10 975-10 990, 1998.

Plane, J. M. C. and Saiz-Lopez, A.: UV-Visible differential optical absorption spectroscopy (DOAS), in: Analytical techniques for atmospheric measurement, edited by: Heard, D. E., Blackwell Publishing, Oxford, 2006.

Preunkert, S., Legrand, M., Jourdain, B., Moulin, C., Belviso, S., Kasamatsu, N., Fukuchi, M., and Hirawake, T.: Interannual variability of dimethylsulfide in air and seawater and its atmospheric oxidation by-products (methanesulfonate and sulfate) at Dumont d'Urville, coastal Antarctica (1999-2003), J. Geophys. Res., 112, D06306, doi:10.1029/2006JD007585, 2007.

Prospero, J. M., Savoie, D. L., Saltzman, E. S., and Larsen, R.: Impact of oceanic sources of biogenic sulphur on sulphate aerosol concentrations at Mawson, Antarctica, Nature, 350, 221-223, 1991.

Rankin, A. M. and Wolff, E. W.: A year-long record of sizesegregated aerosol composition at Halley, Antarctica, J. Geophys. Res., 108(D24), 4775, doi:10.1029/2003JD003993, 2003.

Read, K. A., Lewis, A. C., Salmon, R. A., Jones, A. E., and Bauguitte, S.: $\mathrm{OH}$ and halogen influence on the variability of nonmethane hydrocarbons in the Antarctic Boundary Layer, Tellus B., 59, 22-38, 2007.

Saiz-Lopez, A., Plane, J. M. C., and Shillito, J. A., Bromine oxide in the mid-latitude marine boundary layer, Geophys. Res. Lett., 
31, L03111, doi:10.1029/2003GL018956, 2004.

Saiz-Lopez, A, Mahajan, A. S., Salmon, R. A., Bauguitte, S. J.-B., Jones, A. E., Roscoe, H. K., and Plane, J. M. C.: Boundary Layer Halogens in Coastal Antarctica, Science, 317. 5836, 348-351, doi:10.1126/science.1141408, 2007.

Savoie, D. L., Prospero, J. M., Larsen, R. J., Huang, F., Izaguirre, M. A., Huang, T., Snowdon, T.H., Custals, L., and Sanderson, C. G.: Nitrogen and sulfur species in Antarctic aerosols at Mawson, Palmer Station and Marsh (King George Island), J. Atmos. Chem., 95-122, 1993.

Simpson, W. R., von Glasow, R., Riedel, K., Anderson, P., Ariya, P., Bottenheim, J., Burrows, J., Carpenter, L. J., Frieß, U., Goodsite, M. E., Heard, D. E., Hutterli, M., Jacobi, H.-W., Kaleschke, L., Neff, B., Plane, J., Platt, U., Richter, A., Roscoe, H., Sander, R., Shepson, P., Sodeau, J., Steffen, A., Wagner, T., and Wolff, E.: Halogens and their role in polar boundary-layer ozone depletion, Atmos. Chem. Phys., 7, 4375-4418, 2007, http://www.atmos-chem-phys.net/7/4375/2007/.

Staubes, R. and Georgii H. W.: Biogenic sulfur compunds in seawater and the atmosphere of the Antarctic region, Tellus, 45B, 127-137, 1993.
Toumi, R.: BrO as a sink for dimethylsulphide in the marine atmosphere, Geophys. Res. Lett., 21, 117-120, 1994.

Von Glasow, R., Sander, R., Bott, A., and Crutzen, P. J.: Modelling halogen chemistry in the marine boundary layer, 2, Interactions with sulfur and cloud-covered MBL, J. Geophys. Res., 107(D17), 4323, doi:10.1029/2001JD000943, 2002.

Von Glasow, R. and Crutzen, P. J.: Model study of multiphase DMS oxidation with a focus on halogens, Atmos. Chem. Phys., 4, 589608, 2004, http://www.atmos-chem-phys.net/4/589/2004/.

Wagenbach, D., Ducroz, F., Mulvaney, R., Keck, L., Minikin, A., Legrand, M., Hall, J. S., and Wolff, E. W.: Sea-salt aerosol in coastal Antarctic regions, J. Geophys. Res., 103, 10 961-10 974, 1998.

Wolff, E. W., Legrand, M. R., and Wagenbach, D.: Coastal Antarctic aerosol and snowfall chemistry, J. Geophys. Res., 103, 10927-10934, 1998. 